\title{
From the History of Religions to the Science of Religion in Norway
}

\author{
INGVILD SÆLID GILHUS \& KNUT A. JACOBSEN \\ University of Bergen
}

\begin{abstract}
The focus in this article is on the developments in the study of religion in Norway during the last fifty years, reflecting over continuities and breaks with the past, over changes in themes, theories and methods as well as over relations to the surrounding world.
\end{abstract}

Keywords: Study of Religion, Norway

When Temenos was founded in 1965, Norway had only one professor in the History of Religions, Herman Ludin Jansen, a theologian at the University of Oslo, who was appointed in 1953. Within fifty years the study of religion - or the Science of Religion, religionsvitenskap ${ }^{1}$ - is taught in all the four 'old' universities of Norway. In Oslo, the first chair was set up in 1914 (see below); in Bergen in 1965, ${ }^{2}$ in Trondheim in $1994^{3}$ and in Tromsø in 1994. ${ }^{4}$ There has been a growth in students, departments and chairs - the number of permanent positions in the subject has increased from one in the beginning of the sixties to approximately twenty-five in 2014. Christian theologians, who initially held some of these chairs, have also been replaced by religion scholars educated in the Faculty of Arts/Faculty of Humanities.

The focus in this article is on the developments in the study of religion in Norway during the last fifty years. We will reflect over continuities and breaks with the past, over changes in themes, theories and methods as well as over relations to the surrounding world.

1 Except for the University of Oslo, the name in all the universities is now religionsvitenskap, related to German Religionswissenschaft - 'science of religion'. This term highlights the multidisciplinary character of the subject, which also includes the historical approach (cf. Finnestad 2001, note 22).

2 The first professor, Alv Kragerud, was appointed in 1967 (Thomassen 2011).

3 Nora Ahlberg was appointed in 1996.

4 Juha Pentikäinen was appointed in 1996. 


\section{Focus and Fields}

Wilhelm Brede Kristensen (1867-1953) was the first historian of religions in Norway. He received a research grant (universitetsstipend) at the University of Oslo ${ }^{5}$ in 1898, but was called to the University of Leiden in 1901 to succeed Cornelis P. Tiele (cf. Bremmer 2000, Hjelde 2000). After Kristensen, J. F. Wilhelm Schencke got the research grant (universitetsstipend) in 1901 and was appointed professor July 1st 1914 (Thomassen 2000). Both Kristensen and Schencke had studied under the professor in Egyptology, Jens D. C. Lieblein, ${ }^{6}$ and both took their doctoral degrees on Egyptian religion. ${ }^{7}$

Before Schencke's appointment, there had been a discussion whether the professorship in the History of Religions should be placed in the Faculty of Theology or in the Faculty of Arts. Schencke argued that to qualify as a university subject, all aspects of theology should on principle be subject to critical research (Kyllingstad \& Rørvik 2011, 173), and should therefore be replaced by a secular study of religion. He described the Faculty of Theology as 'the inflamed appendix of the university' ${ }^{8}$, which reflects his difficult relationship to the faculty, but also his progressive views on the scientific study of religion. ${ }^{9}$ The chair was finally placed in the Faculty of Arts, where Schencke was professor for twenty-five years (1914-39). ${ }^{10}$ Georg Sverdrup (1885-1951), a historian with a specialization in Old Norse Religion, suc-

\footnotetext{
5 Oslo was then Kristiania and the university was called Det Kongelige Frederiks Universitet (The Royal Frederick University).

6 There was, however, a wider milieu of academics with an historical interest in the religions - Old Testament theologians, but also professors in Classics, Egyptology and Semitic Language and Culture. One example is Jens D. C. Lieblein (1827-1911), who got a research grant (universitetsstipend) in 1867 and was appointed extraordinary professor in Egyptology at the University of Oslo in 1876. He published books on Egyptian religion. Another example is Samson Eitrem (1872-1966), who was professor in Classics 1914-45, and wrote several books about Greek religion, among them Beiträge zur griechischen Religionsgeschichte, 3 bd., 1910-20; and Opferritus und Voropfer der Griechen und Römer, 1915. Both Lieblein and Eitrem had a wide international publication and were well known outside Norway. Sigurd Hjelde mentions also three theologians from the interwar period as examples of what he calls 'historians of religion in a wider sense' - Eivind Berggrav, Sigmund Mowinkel and Kristian Schjelderup (Hjelde 2008). 7 Kristensen's doctoral thesis was Ægypternes forestillinger om liv etter døden i forbindelse med guderne Ra og Osiris (Kristiania 1896); Schencke's was Amon-Re. En studie over forholdet mellom enhed og mangfoldighed under udviklingen af det xgyptiske gudsbegreb (Kristiania, 1904) (cf. Naguib 2000).

8 Tidens tegn 28.01.1913 ('universitetets betændte blindtarm, som maa opereres vek jo før jo heller').

9 From 1901-1914, Schencke wrote more than hundred articles in newspapers and periodicals (Halden 2007, 147). For references to some of Schencke's many articles on this subject, see Finnestad 2001, 246, note 19.

10 A scientific bibliography of Schencke's works is found in Halden 2007, 285-91.
} 
ceeded him in 1947, but died after four years. ${ }^{11}$ Herman Ludin Jansen (1905-1986) was appointed in 1953 and held the chair to 1975. ${ }^{12}$

Ludin Jansen had not been Schencke's student (Halden 2007, 184). His background was in theology, where he took his doctoral degree in 1940 (Die Henochgestalt: Eine vergleichende religionsgeschichtliche Untersuchung, 1939). His special field of research was the religions of the Middle East and the Mediterranean world, but he also wrote on Buddhism and was interested in Japanese religions. ${ }^{13}$ His language skills included Latin, Greek, Hebrew, Syrian, Arabic, Ancient Egyptian and Coptic, as well as Sanskrit and Avesta, and he published in a wide area of subjects in journals such as Numen, Temenos and Acta Orientalia, but also frequently in Norsk Teologisk Tidsskrift.

He was on the editorial board of Temenos from 1965 till 1986 when he died. ${ }^{14}$ Ludin Jansen published an article in the first issue of the new journal, 'Die Hochzeitriten im Tobitbuch' (Jansen 1965), and four years later an article on Greek religion, 'Die Kassandragestalt in Aischylos' Agamemnon' (Jansen 1969). The last article he ever published was in Temenos as well, but this time the subject was Islam: 'Zur Frage vom Menschenbild im Koran' (Jansen 1980).

Ludin Jansen had a lifelong interest in mysticism, published on Plotin and Meister Eckhart, and was one of the pioneer scholars who studied the Coptic texts from Nag Hammadi, especially the Gospel of Truth (cf. Kværne 1986; 1988). Among his Nordic colleagues, his closest connection was to Geo Widengren. ${ }^{15} \mathrm{He}$ was made doctor honoris causa at the University of Uppsala in 1973. Ludin Jansen wrote course books for secondary schools and universities and articles in newspapers. With Torgny Säve-Söderberg, he formed a Scandinavian Nubia Committee, which organized archaeological expeditions to Nubia in connection with the building of the Aswan dam.

In many ways Herman Ludin Jansen embodied typical traits of the ideal scholar of History of Religions in his own times - he was a prolific author, published on several religions, knew several ancient languages, had an international orientation and promoted the study of the History of

11 Sverdrup's doctoral thesis was Fra gravskikker til dødstro i nordisk bronsealder (1933).

12 Ludin Jansen continued to give lectures two years after he had retired.

13 For a scientific bibliography of Herman Ludin Jansen, see Borgen 1985, 11-14.

14 The two other Norwegians on the editorial board of Temenos in 1965 were, Arvid Kapellrud, who was professor in the Old Testament and Svale Solheim, who was professor in Folkloristics. 15 When a volume of essays on religion in the Graeco-Roman world was presented to Ludin Jansen the year before he died, it included texts by Ludin Jansen himself and, in addition, four contributions from colleagues (Borgen 1985). One of the four, and the only colleague outside Norway, was Geo Widengren. 
Religions in Norwegian society; but it is notable that his background was in Theology. Several of his pupils got positions at the universities, among them Alv Kragerud, who was the first professor at the University of Bergen, but he too was a theologian, and had also worked as a Lutheran minister. ${ }^{16}$

\section{Research Areas and Widening Interests}

The research interests of the three first professors of the History of Religions in Norway were continued by later generations of scholars. Research in Egyptian religion was initiated by Jens Lieblein, and continued by Brede Kristensen and Wilhelm Schencke, and subsequently by the late Ragnhild Bjerre Finnestad and Saphinaz A. Naguib. Sverdrup specialized in Nordic religion. In Sverdrup's field, Gro Steinsland in Old Norse Religion, and Håkan Rydving in Sámi Religion are important.

The most obvious continuity has been in the study of Coptic Christian texts. Schencke gave lectures (for two students!) on the Coptic text Pistis Sophia in 1906 (Ruud 1998, 286). In the autumn of 1955, Ludin Jansen gave his first lectures in Coptic, and the 'Gnostic' Coptic Christian Texts became the most important topic in his department, and especially the texts from Nag Hammadi (Ruud 1998, 290-91; Gilhus 1998). This is still a vibrant research field in Norway. ${ }^{17}$

Following broader political and cultural changes in society, since the 1960s there has been a steady expansion of the discipline, which includes research, education and institutions. From 1960 to 1970, the total number of students at the University of Oslo tripled (16 800 students in 1970) and in 1978 it was decided by the government that a university degree in Science of Religion (University of Bergen) and History of Religions (University of Oslo) should qualify for jobs in the schools. The general growth of the student population and the introduction of non-confessional studies of religion in secondary schools led to a significant increase of students in religion outside the theological faculties. One change was that it became possible to take a

16 Kragerud's doctoral thesis is Die Hymnen der Pistis Sophia, 1967.

17 Among Ludin Jansen's students in Coptic were Peder Borgen, Ingvild Sælid Gilhus, Jacob Jervell, Alv Kragerud and Kari Vogt (Gilhus 1998). Alv Kragerud gave lectures in Coptic at the University of Bergen and supervised Jarl Fossum, Jorunn Jacobsen, Gro Steinsland and Einar Thomassen in the field of Coptic and Gnostic texts. In the next generation of scholars who specialize in Coptic texts are Hugo Lundhaug and Christian Bull. Several of these scholars have taken doctoral degrees based on Nag Hammadi texts. Einar Thomassen initiated and was the leader of the Nordic Nag Hammadi and Gnosticism Network, a network that also included scholars from other parts of the world. 
cand.philol. (Master's) degree in Science of Religion/History of Religions. This degree was meant to cater for the demand for teachers in the high schools and to replace the old research degree, the Magister Artium.

From being a country with a huge Christian dominance, the society began in the late 1960s and early 1970s a slow transition towards a multicultural and multi-religious society, and since the 1970s there has been a gradually increasing public visibility of Muslim, Buddhist, Hindu and Sikh religious institutions, New Age spirituality, Yoga traditions, and Buddhist and Hindu spiritualities. Black metal and Satanism ${ }^{18}$ and popular religion ${ }^{19}$ have also attracted attention. In line with this development, the sphere of interest of the scholars of religion has expanded as well. ${ }^{20}$

Indian and East Asian religions, and Islam, have been studied in Science of Religion departments, but also by missionaries and theologians in the Faculty of Theology, with a focus on mission and the dialogue perspective, and in departments of South Asian and East Asian languages and cultures, as part of language and culture studies. The dialogue perspective is mostly considered irrelevant for the Science of Religion, because the starting point of this dialogue is in the Christian world view, and other religions are understood from a Christian perspective. In Norway, the study of religion in departments of South Asian and East Asian languages and cultures has been especially important for the study of Indian and to a lesser degree the East Asian religions. The challenge for Science of Religion posed by the study of Indian religions is that the scholar of religions has to maintain the philological rigour of Indology and at the same time relate to the wider field of Religious Studies. The University of Oslo has a solid tradition in Indology, with Sten Konow (1867-1948) as professor in Indian philology already from 1919 to 1937. Georg Morgenstierne (1892-1978) was the next important linguist on South Asian languages at the University of Oslo. The professorship in Sanskrit at the University of Oslo has been an important resource for students of religion at that university: Georg von Simson was

18 Asbjørn Dyrendal at NTNU (Norwegian University of Science and Technology [Norges teknisk-naturvitenskapelige universitet] in Trondheim) has been leading in this field of study.

19 With studies by Dag Øistein Endsjø and Liv Ingeborg Lied in religion and popular culture. Endsjø and Lied are experts in ancient religions.

20 When Ragnhild Bjerre Finnestad wrote an article on the study of religion in Norway in the mid-1990s (Finnestad 2001), she pointed at the multiplication of Gnostic studies and the important addition of 'Coptic Christianity, Buddhism, Tibetan bon-religion, African religion, and women's traditions' (Finnestad 2001, 247). The years that have lapsed since then have slightly changed the picture and brought new additions to our field such as Hinduism, Sikhism, Jainism, Zoroastrianism, New Age, Sami religion, and Satanism. 
professor from 1977 to 2003 . At the University of Bergen, the only South Asian language taught, irregularly and offered as a part of the education in the science of religions, is Sanskrit. A particular strength at the University of Oslo has been the study of Buddhism (Per Kværne, Jens Braarvig, Hanna Havnevik and Torkel Brekke), and at the University of Bergen the study of Hinduism (Knut A. Jacobsen and, from 2013, Istvan Keul). Buddhist studies at Oslo have focused on Mahāyāna Buddhism, and religion in Tibet in particular. Per Kværne has published extensively on Bon religion, Jens Braarvig on Mahāyāna texts, Hanna Havnevik on Buddhist nuns and Torkel Brekke on Buddhism and violence. In Hindu Studies at Bergen, Knut A. Jacobsen has published extensively on the plurality of Sāmkhyayoga traditions past and present, Hindu pilgrimage traditions, procession rituals, Hindu traditions and nature, and the Hindu diaspora, rituals and identity. The six-volume Brill's Encyclopedia of Hinduism (Jacobsen 2009-2014) and the Brill's Encyclopedia of Hinduism Online ${ }^{21}$ are both edited from the University of Bergen. The study of East Asian Religions has mainly taken place in departments of East Asian languages and illustrates that the study of religion is a much larger field than the academic discipline of the Science of Religion.

The situation is somewhat similar within the study of Islam. In the History of Religions department in Oslo, Kari Vogt has been the most visible scholar, partly because of her research on the many diasporas in Norway from countries dominated by Islam. In the other Science of Religion departments, important contributions have been made to the study of Islam in the fields of ritual and iconography, family law, the Quran, Islamic historiography, and 'lived Islam' (Marianne Bøe, Mona Farstad, Ingvild Flaskerud, Ulrika Mårtensson, Richard Johan Natvig). Research on Islamic history and societies and the relevant languages has also had a strong presence in departments of History, Social Anthropology, in language departments, and in the Faculty of Theology.

Since the 1990s there have been several research projects and student courses on New Age religions, mainly at the University of Bergen, some with external funding. ${ }^{22}$ This is probably the area where the most Master's theses have been written in Norway - the number is approximately one hundred (Gilhus \& Mikaelsson 2012). Another area of increased interest is the religions of immigrants and their descendants (see Jacobsen 2011; Jacobsen \& Kumar 2004; Jacobsen \& Raj 2008), including participation in a

$21<\mathrm{http}$ //www.brill.com/publications/online-resources/brills-encyclopedia-hinduism-online> 22 'Theosophy in Norway' (1992-1998) and 'Myte, magi and mirakel i møte med det moderne' (Myth, magic and miracle meet modernity), both at the University of Bergen (1994-1997). 
Nordic research project on the Sikhs in the Nordic countries (Jacobsen and Myrvold 2011; 2012). ${ }^{23}$

\section{Theories and Methods}

This widening of interest with regard to topics has been matched by a multiplication of methods and new theoretical approaches. There is, however, also a strong continuity with the past, especially in textual studies and philology (cf. Stausberg 2009b, 277).

The first professors worked mainly with the past and with ancient texts: their main instruments were philology and a historical-critical approach. This means that their approaches were much the same as those of scholars in the Old and the New Testament, Classics, and Oriental languages. When Ludin Jansen had sabbaticals, stand-ins for him were usually colleagues in these fields, which shows the proximity between the History of Religions and these types of studies.

Schencke saw knowledge of the languages as absolutely necessary to understand religion, a view that his successors shared. He gave courses in Old Egyptian, Arabic and Hebrew language and grammar (Halden 2007, 179; Finnestad 2001, 246), while Ludin Jansen gave lectures in Egyptian, Coptic and Syriac. Budding scholars in religion usually learnt the trade by translating and commenting on ancient texts together with the professor. It was typically learning by doing, similar to how a craftsman learnt a trade. Frequently the professor gave lectures and seminars built on his own research, which ended in publications. The study of the past and the textual approach are still very much alive, especially at Bergen and Oslo.

Parallel with a focus on historical texts in the students' curriculum went an interest in phenomenology. As in other countries, the phenomenology of religion was seen as the glue that kept the diversity of religions together. Inspired by Brede Kristensen, Schencke offered lectures in phenomenology (Halden 2007,179), as did Ludin Jansen and Kragerud. In the curricula in the 70s and 80s, the phenomenologies of van der Leeuw and Mircea Eliade were kept in balance by the systematic studies of Geo Widengren. In this period the students at the University of Bergen had two major examinations, one about the history of religion and one where they applied a systematic approach to comparative material. Diachronic and synchronic perspectives

23 'Sikh Identity Formation: Generational Transfer of Traditions in the Nordic Countries' (2009-2013), a cooperation between Lund University, University of Bergen, University of Copenhagen and University of Jyväskylä. 
were ideally meant to work together. During the 80s, however, phenomenology came under increasing criticism, and today this approach is no longer important (Thue 1996).

Religion was now seen less as something sui generis and more like something that needed definition and explanation. Gradually new approaches emerged. Ragnhild Bjerre Finnestad remarks appropriately that the result of cultural and social aspects being taken 'into consideration to an unprecedented degree', is that

the study of religion as a historical and cultural phenomenon has at its disposal a highly variegated arsenal of theoretical and methodological approaches. The Norwegian academic milieu has largely acted eclectically towards this multi-disciplinary plurality and has not considered this a drawback. Rather, a marked reluctance to confine the discipline to the one or the other schools can be seen. (Finnestad 2001, 248.)

As the Science of Religion has liberated itself from Theology and Biblical Studies, the focus in religion has expanded beyond the texts, and scholars have to a larger degree focused on the present and on religion not as texts, but as something people do, and ethnographic field work (sadly, however, often without proper language skills) has to some degree replaced the emphasis on philological training and the work with texts.

From the study of religion as something that the students learned by being taught languages and imitating the professors, there is today a focus in the education of students on theory and method, and books in method and methodology have been published (see below).

Since around 1980, there has been close co-operation between historians of religion in Denmark and Norway. The journal Chaos was initiated in Copenhagen by Jørgen Podeman Sørensen 1982, but was from 1986 (nr. 5) a joint venture between Copenhagen and Bergen. Later other universities in Norway were included and from 2006 (nr. 46) also Swedish universities joined. The co-operation includes a yearly conference. The Norwegian journal, Din: tidsskrift for religion og kultur, was started in 1999. This is the first Norwegian journal in the field.

The roles of women began to change in the 70s. Feminist studies were made part of the curriculums and gave new perspectives to traditional texts. ${ }^{24}$ At the University of Bergen there was in the 1980s a predominance

24 One example is Lisbeth Mikaelsson, 'Sexual Polarity: An Aspect of the Ideological Structure in the Paradise Narrative, Gen.2, 4-3, 24.' Temenos 16 (1980), 84-91. 
of female scholars in religion, and from 1982 till today, fifteen women have taken their doctoral degrees at Bergen. ${ }^{25}$

\section{Textbooks and Historical Survey Works}

The last fifteen years have been marked by the publication of a large number of significant textbooks, historical surveys, and books in theories of religion and methods and methodology, both in Norwegian and English, especially from religion scholars at the University of Bergen. The books have typically focused on the historical emergence of a tradition and have been written by specialists in the history of that particular religion's traditions, geographical distribution and languages. The phenomenology of religion has been downplayed. Knut A. Jacobsen has published historical surveys on Buddhism (2000), Hinduism (2003), Sikhism (2006) and Jainism (2013), Michael Stausberg on Zoroastrianism (2008), Kari Vogt on Islam (1993; 2005), and Einar Thomassen (with Tarald Rasmussen) on Christianity (2000). Surveys include Verdensreligioner $i$ Norge (World Religions in Norway) (Jacobsen 2011 [first edition 2001]), which is now in its third edition, Verdens levende religioner (The World's Living Religions) (Gilhus \& Mikaelsson, 2007a), and Oldtidens religioner: Midtøstens og Middelhavsområdets religioner (Ancient Religions: The Religions of the Middle East and the Mediterranean) (Gilhus \& Thomassen 2010). Norges religionshistorie (Religious History of Norway) was edited by the folklorist Arne Bugge Amundsen, and the contributing authors included two historians of religions, Brita Pollan and Anne Stenvold (2005).

Universitetsforlaget's series Hva er ('What is') has included several volumes on religions written by scholars from Religion departments: on Islam (Vogt 2007), Hinduism (Jacobsen 2009), new religions (Kraft 2011), fundamentalism (Brekke 2007), and also a volume on the discipline of the Science of Religion (Gilhus \& Mikaelsson 2007b). The last twenty years have also been a productive period for publication of popular translations of selections of religious texts into Norwegian, especially in the series Verdens hellige skrifter (Sacred Texts of the World) (De norske bokklubbene), with around 90 titles so far. One of the three series editors is Jens Braarvig, a scholar of religion at the University of Oslo. Books on theory and method have also been published mainly from the University of Bergen: Nytt blikk på religion: studiet av

25 Ingvild Sælid Gilhus, Ragnhild Bjerre Finnestad, Saphinaz Naguib, Lisbeth Mikaelsson, Henny Hägg, Siv Ellen Kraft, Liv Ingeborg Lied, Anne Stensvold, Mette Ramstad, Ingvild Flaskerud, Gerd Marie Ådna, Sissel Undheim, Birte Brekketo, Marianne Bø, Mona Farstad. Most of them now hold university chairs; seven are professors. 
religion i dag (A New Perspective on Religion: the Study of Religion Today) (Gilhus \& Mikaelsson 2001) and the edited volumes Contemporary Theories of Religion: a Critical Companion (Stausberg 2009a), The Routledge Handbook of Research Methods in the Study of Religion (Stausberg \& Engler 2011), and Metode i religionsvitenskap (Method in the Science of Religion) (Kraft \& Natvig 2006).

\section{The Relationship to Theology}

As we have seen, the institutional framework for the study of religion was an issue from the very beginning of the study of religion in Norway. Its first phase was in several ways influenced by the conflict with theology. ${ }^{26}$ Schencke and Ludin Jansen were both educated at the Theological Faculty, where Ludin Jansen had a research grant (universitetsstipend) and later an associate professorship (1939-1953), before he was appointed professor in the History of Religions (Kværne 1988; Thelle 2000, 24). For Schencke, a driving force in his work was his intense opposition to theology, and one of the things that interested him was the secular origin of Christianity and Judaism, while Ludin Jansen saw History of Religions more as a complement to theology than as a challenge.

In general, the relationship to theology continued to be difficult, since the identity of the History of Religion was partly constructed on its differentiation from theology, with theology as the significant other (Gilhus 2011). One special challenge was the study of Christianity. At the University of Oslo, Studies in Christianity were accepted as a field in its own right in 1957 (Ruud 1998, 292). From 1974, there were two separate sections in the Department of the History of Religions: one for the History of Religions and one for Study of Christianity (Ruud 1998, 223), a very unfortunate situation. In 1989, however, the Study of Christianity was transferred to the Theological Faculty (Ruud 1998, 294). A similar development took place in Bergen, but here the study of Christianity as a separate subject was closed down in 1991, and Christianity was from then on studied under the aegis of the Science of Religion and in a comparative context.

At the University of Tromsø, the main focus has been on indigenous religion, including Sami religion, and on religion in Northern Norway and New Age religion..$^{27}$ Parallel to the Science of Religion, the university also offers Theology, and the two studies have some courses in common.

26 According to Sissel Halden no corresponding initial clash with theology occurred in Denmark and Sweden (Halden 2007, 251-79).

27 With Siv-Ellen Kraft, Roald Kristiansen, James Lewis and Bjørn Ola Tafjord.. 
A trend seems to be that the theological institutions are eager to include the Science of Religion as one of their sub fields, one reason being to attract a higher number of students in their programs.

The Science of Religion in Norway is a small discipline, and only one of several disciplines that study and educate in religion. The theological and the religious education institutions are much larger in terms of numbers of teachers and students, and the education of teachers for elementary schools and junior high schools is to a large degree defined as the task of these institutions. Religious education in these colleges is based on the study of Christianity, and although the curriculum has been expanded to include also other religions so as to reflect the changed curriculum in the elementary and junior high schools, these religions are mainly understood in light of Christianity and with Christianity as the normative religion. Many of the teachers at these theological and religious education institutions have their education from accredited public and private theological institutions such as the University of Oslo Faculty of Theology,, MF Norwegian School of Theology (Oslo), NLA University College (Bergen), and MHS School of Mission and Theology (Stavanger). The majority of those who teach religion in elementary schools and junior high schools are educated not in the Science of Religion at the universities, but in religious education at these and other teacher colleges, and by teachers who have been trained mainly in theology and the study of Christianity. Although the Science of Religion has expanded to all the 'old' universities in Norway, religion continues to be taught in several other disciplines, such as Theology and Religious Education, and numerically the Science of Religion is the smallest of these disciplines. So even though the theologians of the early stages of the History of Religion in Norway were gradually replaced by persons with no connection to the theological institutions and educated in the Humanities, giving rise to the Science of Religion, this has not been the case in other education institutions, and the education of teachers for elementary and junior high schools is still, unfortunately, dominated by Christian theological ideology.

Liberation from theology has been a main motivation and an important element in the identity of the Science of Religion in Norway. Theology was the significant other, especially for those who worked on Christian traditions and religions that had influenced the origin of Christianity and its early development. For the study of Asian religions, on the other hand, Theology has been mostly irrelevant, and the significant others have been Indology, Chinese Studies and Japanese Studies. 


\section{Conclusion: The Study of Religion in Norway}

The development of the Science of Religion in Norway had an international dimension from the beginning, and its history is increasingly difficult to tell as a national history. It is an international enterprise, with participation in international research networks, journals and organizations. Several professors have their doctoral degrees in Religious Studies from abroad: Einar Thomassen from the University of St. Andrew's (School of Divinity), and Knut A. Jacobsen from the University of California at Santa Barbara (Religious Studies). Torkel Brekke has his degree from the Faculty of Oriental Studies, University of Oxford. In addition, a growing number of persons from abroad work in departments of the Science of Religion in Norway: Istvan Keul, Håkan Rydving and Michael Stausberg at the University of Bergen, Gabriel Levy at NTNU in Trondheim, and James Lewis at the University of Tromsø. Those with training and experiences from abroad have brought important international impulses to Norway. They have provided valuable correctives and brought with them new fields of specialization.

Research in the Science of Religion in Norway covers a large number of themes and is not dominated by a single theoretical school or approach. Geographically the research focuses in particular on the Middle East and the Mediterranean, India and South Asia, and Norway, and thematically on such varied fields as Buddhism, Christianity, Diaspora Studies, Hinduism, Gender Studies, Gnosticism, Iconography, Islam, Jainism, Methods and Theories of Religion, New Age, Religion and Nature, Politics, Popular Culture, Public Religion, Ritual Studies, Sami religion, Sacred Animals, Satanism, Sikhism, and Zoroastrism.

Significantly, most of the professors in the Science of Religion in Norway now have their education and background in the Science of Religion. This is an important milestone in the institutional development.

\section{Bibliography}

Amundsen, Arne Bugge (ed.)

2005 Norges religionshistorie. Oslo: Universitetsforlaget.

Borgen, Peder (ed.)

1985 The Many and the One. Essays on Religion in the Graeco-Roman World. Presented to H. Ludin Jansen (Relieff). Trondheim: Tapir. 


\section{Brekke, Torkel}

2007 Hva er fundamentalisme. Oslo: Universitetsforlaget.

Bremmer, Jan. $\mathbf{N}$.

2000 W. Brede Kristensen and the Religions of Greece and Rome. - Sigurd Hjelde (ed.), Man, Meaning and Mystery. 100 Years of History of Religions in Norway. The Heritage of W. Brede Kristensen, 115-30. Leiden: Brill.

\section{Eitrem, Samson}

1910-20 Beiträge zur griechischen Religionsgeschichte, 3 bd. Kristiania: Jacob Dybwad.

1915 Opferritus und Voropfer der Griechen und Römer. Kristiania: Jacob Dybwad.

\section{Finnestad, Ragnhild Bjerre}

2001 The Study of Religions in Norway. - Method \& Theory in the Study of Religion, 13, 243-53.

\section{Gilhus, Ingvild Sælid}

1998 Sophias tjenere: gnostisisme og gnostiske studier i Norge. - Inger Marie Ruud \& Sigurd Hjelde (eds), Enhet $i$ mangfold? 100 år med religionshistorie i Norge, 62-80. Oslo: Tano Aschehoug.

2011 The non-confessional study of religion and its normative dimensions. - Jan-Olav Henriksen (ed.), Difficult Normativity: Normative Dimensions in Research on Religion and Theology, 95-107. Frankfurt am Main: Peter Lang.

\section{Gilhus, Ingvild Sælid \& Lisbeth Mikaelsson}

2001 Nytt blikk på religion: studiet av religion $i$ dag. Oslo: Pax.

2007b Hva er religion. Oslo: Universitetsforlaget.

2012 Bibliografisk oversikt over nyreligiøsitetsforskningen i Norge. - Aura. Tidsskrift för akademiska studier av nyreligiøsitet, 4, 21-45.

Gilhus, Ingvild Sælid \& Lisbeth Mikaelsson (eds)

2007a Verdens levende religioner. Oslo: Pax.

Gilhus, Ingvild Sælid \& Einar Thomassen

2010 Oldtidens religioner:Midtøstens og Middelhavsområdets religioner. Oslo: Pax.

\section{Halden, Sissel}

2007 Wilhelm Schencke - en omstridt pioneer. Etableringen av religionshistorie som et akademisk fag $i$ Norge. Doktorgradsavhandling, Det humanistiske fakultet, Universitetet i Oslo.

\section{Hjelde, Sigurd}

2000 From Kristiansand to Leiden: The Norwegian Career of W. Brede Kristensen. - Sigurd Hjelde (ed.), Man, Meaning and Mystery. 100 Years of History of Religions in Norway. The Heritage of W. Brede Kristensen, 205-22. Leiden: Brill. 
2008 Religionswissenschaft zwischen Rationalismus und Irrationalismus: Ein norwegisches Beispiel: Der Fall Kristian Schelderups. - Horst Jungiger (ed.), The Study of Religion under the Impact of Fascism, 491-509. Leiden: Brill.

\section{Jacobsen, Knut A.}

2000 Buddhismen. Oslo: Pax. Swedish translation, Buddhismen: Kultur, historia, traditon, Stockholm: Natur og Kultur, 2002.

2003 Hinduismen. Oslo: Pax. Swedish translation, Hinduismen: Historia, tradition, mångfold, Stockholm: Natur og Kultur, 2004.

2006 Sikhismen: Historie, tradisjon og kultur. Kristiansand: Høyskoleforlaget.

2009 Hva er hinduisme. Oslo: Universitetsforlaget.

2013 Jainismen: religion, historie og ikkevold. Oslo: Cappelen Damm Akademisk.

Jacobsen, Knut A. (ed.)

2011 Verdensreligioner i Norge. 3d. ed. Oslo: Norwegian University Press.

2009-2014 Brill's Encyclopedia of Hinduism, 6 Volumes. Leiden: Brill.

Jacobsen, Knut A. \& P. Pratap Kumar (eds)

2004 South Asians in the Diaspora: Histories and Religious Traditions. Leiden: Brill.

Jacobsen, Knut A. \& Kristina Myrvold (eds)

2011 Sikhs in Europe: Migration, Identity, and Representations. Farnham: Ashgate.

2012 Sikhs Across Borders: Transnational Practices among European Sikhs. London: Bloomsbury

Jacobsen, Knut A. \& Selva J. Raj (eds)

2008 South Asian Christian Diaspora: Invisible Diaspora in Europe and North America. Farnham: Ashgate.

\section{Jansen, Herman Ludin}

1939 Die Henochgestalt: Eine vergleichende religionsgeschichtliche Untersuchung. Oslo: Det Norske Videnskaps-Akademi.

1965 Die Hochzeitriten im Tobitbuch. - Temenos 1, 142-9.

1969 Die Kassandragestalt in Aischylos' Agamemnon. - Temenos 5, 107-19.

1980 Zur Frage vom Menschenbild im Koran. - Temenos 16, 56-61.

\section{Kraft, Siv-Ellen}

2011 Hva er nyreligiøsitet. Oslo: Universitetsforlaget.

Kraft, Siv-Ellen \& Richard Natvig (eds)

2006 Metode i religionsvitenskap. Oslo: Pax.

Kragerud, Alv

1967 Die Hymnen der Pistis Sophia. Oslo: Universitetsforlaget. 


\section{Kristensen, Brede}

1896 Ægypternes forestillinger om liv etter døden i forbindelse med guderne Ra og Osiris. Kristiania.

\section{Kværne, Per}

1986 Herman Ludin Jansen (1905-1986). - Temenos 22, 142-144.

1988 Minnetale over Professor Herman Ludin Jansen holdt i den historisk-filosofiske klasses møte den 13. November 1986. - Det Norske Videnskaps-Akademi Årbok 1986, 217-19. Oslo: Universitetsforlaget.

\section{Kyllingstad, Jon Røyne \& Thor Inge Rørvik}

2011 1870-1911: Vitenskapenes universitet (Universitetet i Oslo 1811-2011, bind 2), Oslo: Unipub.

\section{Mikaelsson, Lisbeth}

1980 Sexual Polarity: An Aspect of the Ideological Structure in the Paradise Narrative, Gen. 2, 4-3, 24. - Temenos, 16, 84-91.

\section{Naguib, Saphinaz-Amal}

2000 Lieblein, Kristensen and Schencke and the Quest for Egyptian Monotheism. - Sigurd Hjelde (ed.), Man, Meaning and Mystery. 100 Years of History of Religions in Norway. The Heritage of W. Brede Kristensen, 101-13. Leiden: Brill.

\section{Ruud, Inger Marie}

1998100 år med religionshistorie i Norge: En faghistorisk oversikt. - Inger Marie Ruud and Sigurd Hjelde (eds.), Enhet i mangfold? 100 år med religionshistorie i Norge, 281-310. Oslo: Tano Aschehoug.

\section{Schencke, Wilhelm}

1904 Amon-Re. En studie over forholdet mellom enhed og mangfoldighed under udviklingen af det xgyptiske gudsbegreb. Kristiania: Cammermeyer.

\section{Stausberg, Michael}

2008 Zarathustra and Zoroastrianism: a short introduction, translated by Margret Preisler-Weller; with a postscript by Anders Hultgård. London: Equinox.

2009a Contemporary Theories of Religion: a Critical Companion. London/New York: Routledge.

2009b The study of religion(s) in Western Europe III: Further developments after World War II. - Religion 39, 261-82.

Stausberg, Michael \& Steve Engler (eds)

2011 The Routledge Handbook of Research Methods in the Study of Religion. London/New York: Routledge.

\section{Sverdrup, Georg}

1933 Fra gravskikker til dødstro i nordisk bronsealder. Oslo: Det Norske Videnskaps-Akademi. 


\section{Thelle, Rannfrid I.}

2000 Historiens utfordringer: Gammeltestamentlig forskning ved Det teologiske fakultet i det 20. Århundre. - Norsk Teologisk Tidsskrift 101, 17-31.

\section{Thomassen, Einar}

2000 Wilhelm Schencke - Norway's First Professor in History of Religions. - Sigurd Hjelde (ed.), Man, Meaning and Mystery. 100 Years of History of Religions in Norway. The Heritage of W. Brede Kristensen, 223-36. Leiden: Brill.

2011 Minnetale over Professor Alv Kragerud holdt i fellesmøte i Bergen den 4. November 2010. - Det Norske Videnskaps-Akademi. Årbok 2010, 174-9. Oslo: Novus forlag.

\section{Thomassen, Einar \& Tharald Rasmussen}

2000 Kristendommen: en historisk innføring. Oslo: Universitetsforlaget.

Thue, Fredrik W.

1996 Det humanistiske fagfeltets historie. - Nils Roll-Hansen et al. Universitetet $i$ Bergens historie, volume II, 434-579. Bergen: Universitetet i Bergen.

\section{Vogt, Kari}

1993 Islams hus: verdensreligion på fremmarsj. Oslo: Cappelen.

2005 Islam: tradisjon, fundamentalisme og reform. Oslo: Cappelen.

2007 Hva er Islam. Oslo: Universitetsforlaget. 